IZA DP No. 9745

The Effect of Housing Wealth on Labor Force Participation: Evidence from China

Shihe Fu

Yu Liao

Junfu Zhang

February 2016 


\title{
The Effect of Housing Wealth on Labor Force Participation: Evidence from China
}

\author{
Shihe Fu \\ Southwestern University of Finance and Economics \\ Yu Liao \\ Clark University \\ Junfu Zhang \\ Clark University and IZA \\ Discussion Paper No. 9745 \\ February 2016 \\ IZA \\ P.O. Box 7240 \\ 53072 Bonn \\ Germany \\ Phone: +49-228-3894-0 \\ Fax: +49-228-3894-180 \\ E-mail: iza@iza.org
}

\begin{abstract}
Any opinions expressed here are those of the author(s) and not those of IZA. Research published in this series may include views on policy, but the institute itself takes no institutional policy positions. The IZA research network is committed to the IZA Guiding Principles of Research Integrity.

The Institute for the Study of Labor (IZA) in Bonn is a local and virtual international research center and a place of communication between science, politics and business. IZA is an independent nonprofit organization supported by Deutsche Post Foundation. The center is associated with the University of Bonn and offers a stimulating research environment through its international network, workshops and conferences, data service, project support, research visits and doctoral program. IZA engages in (i) original and internationally competitive research in all fields of labor economics, (ii) development of policy concepts, and (iii) dissemination of research results and concepts to the interested public.
\end{abstract}

IZA Discussion Papers often represent preliminary work and are circulated to encourage discussion. Citation of such a paper should account for its provisional character. A revised version may be available directly from the author. 


\section{ABSTRACT}

\section{The Effect of Housing Wealth on Labor Force Participation: Evidence from China*}

This paper uses the 2011 China Household Finance Survey data to estimate the effect of change in housing value on homeowners' labor force participation. Using the average housing capital gains of other homes in the same community as an instrument for the housing capital gains of a given household, we find that a 100 thousand yuan increase in housing value leads to a 1.37 percentage point decrease in female homeowners' probability of participating in the labor force and a 1.49 percentage point increase in their probability of becoming housewives. We find little effect on men's labor force participation.

JEL Classification: J21, J22, R20, R30

Keywords: housing wealth effect, housing price, labor supply, labor force participation

Corresponding author:

Junfu Zhang

Department of Economics

Clark University

950 Main Street

Worcester, MA 01610

USA

E-mail: juzhang@clarku.edu

\footnotetext{
${ }^{*}$ We thank Albert Saiz and Siqi Zheng for their editorial guidance. We have benefitted from comments and suggestions by Corrado Giulietti, Guojun He, Sharon Pailler, Zhong Zhao, Klaus F. Zimmermann, two anonymous referees and conference participants at Tsinghua University, Shanghai University of Finance and Economics, Renmin University of China, and the China Economist Society 2015 annual conference. All remaining errors are our own.
} 


\section{Introduction}

Along with rapid economic growth, China's urban housing and labor markets experienced substantial structural changes during the past two decades. Chinese housing markets expanded in the 1990s when the central government started to implement comprehensive reforms to privatize housing properties in cities; by 2011 nearly $90 \%$ of urban families were homeowners (Gan et al., 2013). Meanwhile, there has been an enormous housing price appreciation. According to the National Bureau of Statistics, during 2000-2013, average nominal housing price increased from 1,948 to 5,850 yuan per square meter (Figure 1 ). Real housing prices have been growing $10.5 \%$ annually in the 31 second-tier cities during 2003-2013, and 13.1\% annually in the four first-tier cities: Beijing, Shanghai, Guangzhou, and Shenzhen (Fang et al., 2015).

In the meantime, Chinese urban labor markets also experienced a radical transition. The central planning system once guaranteed job opportunities to urban residents; however, massive layoffs occurred during the market-oriented reforms of the 1990s. Simultaneously, an increasing number of rural migrants entered the urban labor market. As a result, labor force participation rate declined and the unemployment rate rose (Feng et al., 2015). Since the early 2000s, labor force participation for men rebounded from the historically low levels of the 1990s, but has been stagnant for women (Figure 1).

This paper examines the link between housing and labor markets in urban China. Specifically, we test whether changes in housing wealth affect labor force participation. The large variations in housing price appreciation across Chinese cities provide an ideal context for us to explore these effects.

The wealth effect on leisure consumption and labor supply is a fundamental economic question that has attracted much attention from scholars. A few studies explore these dynamics using inheritance, lottery gains, housing voucher or rental subsidies as a positive income or wealth shock. Holtz-Eakin et al. (1993) find that large inheritances depress labor force participation in the U.S. Using data from the Panel Study of Income Dynamics and Federal Estate Tax returns in the U.S., Joulfaian and Wilhelm (1994) find that inheritance income reduces working hours, but this effect is small. Brown et al. (2010) find that inheritance income increases older workers' probability of retiring, and this effect is larger if the inheritance is unexpected. Using survey data of lottery players, Imbens et al. (2001) find that large 
lottery winnings reduce winners’ working hours and labor force participation. Jacob and Ludwig (2012) and Fischer (2000) find that receiving housing vouchers or rental subsidies reduces labor force participation of recipients. These findings suggest that an increase in wealth is likely to reduce labor supply.

Changes in housing wealth demonstrate similar dynamics; several studies document a negative association between housing price appreciation and labor supply. ${ }^{1}$ Henley (2004) finds that housing price appreciation significantly reduces women's working hours in Britain. Farnham and Sevak (2007) find that a $10 \%$ increase in housing wealth reduces the expected retirement age by 3.5 to 5 months in the U.S. Disney and Gathergood (2014) show that, in Britain, housing price appreciation reduces young homeowners' labor force participation and working hours. Milosch (2014) finds that a positive housing price shock decreases married female homeowners' working hours and this effect is larger for highly educated, high income married women with children. However, housing price appreciation can also signal high costs of living and lead to more labor supply (Johnson, 2014); He (2015) provides such evidence based on 1997-2008 British Household Panel Survey data. Therefore, the net effect of housing wealth change on labor supply remains an empirical question.

The effects of housing capital gains on labor supply may be heterogeneous due to demographic characteristics. In cities with growing housing prices, renters may need to work more and save more (Sheiner, 1995). In Britain, housing capital gains have little effect on middle-aged homeowners' employment or working hours (Disney and Gathergood, 2014). In the U.S., the effect of housing price shocks on labor supply is particularly strong for high income, high education women with young children at home (Milosch, 2014).

Most of these studies analyze individual-level outcomes but use change in housing prices at a broad geographic area (county, city, or metropolitan area) level as a proxy for individual households' housing wealth change. Without housing wealth information at the household level, these estimates may be biased because many unobserved location-specific attributes likely confound housing price change. Endogeneity issues may also arise because workers tend to sort into different

\footnotetext{
${ }^{1}$ Other studies estimate the effect of housing wealth change on goods consumption (Carroll and Zhou, 2010; Campbell and Cocco, 2007; Case et al., 2005, 2013), college enrollment (Lovenheim, 2011; Cooper and Luengo-Prado, 2015), female fertility rate (Dettling and Kearey, 2014; Lovenheim and Mumford, 2013), and entrepreneurship (Adelino et al., 2015; Harding and Rosenthal, 2013).
} 
locations with specific housing price dynamics based on unobserved personal attributes and income expectations (Starkey and Port, 1993; Moretti, 2013). Using instrumental variables for local housing prices cannot solve the sorting bias issue since the instruments need to be at the local level and unobserved individual preferences may correlate with even exogenous location attributes due to sorting. For example, using natural amenities or geographic features as instruments for housing prices is still problematic if workers with unobserved high ability strongly prefer natural amenities and disproportionally sort into such locations.

Our study differs from the existing literature in two major aspects. First, we use a new micro dataset - the 2011 China Household Finance Survey data - to estimate the effect of a change in housing value on homeowners' labor force participation in urban China. This dataset contains detailed information on housing and other assets for each household, including the purchasing price and current value of each housing unit (up to three housing units for each household), as well as detailed demographic information. This enables us to compute each household's housing capital gain and estimate its effect on labor supply. Second, to address possible measurement error in self-reported housing value and potential omitted variables, such as individual workers' income expectation and preferences for urban amenities, we use the average housing capital gain of households (excluding the household in question) in the same community as an instrument variable for change in housing value. This instrumental-variable (IV) approach is intuitively appealing: a homeowner's housing price change should be highly correlated with his or her neighbors' housing price change, but whether this homeowner decides to work or not should not be affected directly by the neighbors' housing price changes.

Our IV estimation results show that a 100 thousand yuan increase in housing value decreases female homeowners' probability of joining the labor force by 1.37 percentage points. This effect is stronger for young women with children. However, an increase in housing value has little effect on men's labor force participation. We also find that a 100 thousand yuan increase in housing value increases women's probability of becoming housewives by 1.49 percentage points, which is consistent with previous findings that women tend to decrease labor supply in response to capital gains and switch to alternative activities such as home production or taking care of children (Henley, 2004; Disney and Gathergood, 2014; Milosch, 2014). We also find evidence that increased housing capital gains have a slight positive effect on men's 
employment rate, but no effect on retirement age.

Our findings provide some early empirical evidence on the effect of housing capital gains on labor market outcomes in urban China. Housing prices have been growing rapidly in China during the past two decades. With no property tax on homes, housing capital gains have all accrued to homeowners. Understanding the social and economic consequences of this housing wealth effect in China is very important for policymakers but relevant empirical evidence is scarce. This study aims to make such a contribution.

The rest of the paper is organized as follows. Section 2 introduces the data and specifies the econometric model. Section 3 discusses identification issues. Section 4 presents the results and Section 5 concludes.

\section{Data and Empirical Specification}

We use the 2011 China Household Finance Survey (CHFS) data, which is similar to the Survey of Consumer Finance data in the U.S. It is the first micro dataset on household finance behavior in China. The survey employs a stratified three-stage, probability proportion to size (PPS) random sample design, and the sample is representative of households nationwide. ${ }^{2}$ The 2011 sample covers 25 provinces, 65 cities, 80 counties, and 320 communities, including 8,438 households and 29,234 individuals.

The CHFS data contains detailed information on household finance including financial assets, non-financial assets, debts, insurance, income, and consumption, as well as rich demographics variables. The survey asks how many housing units a household owns and records housing attributes for up to three housing units. Housing attributes include floor area, purchase price, purchase year, self-reported current value, location of the first housing unit, and so forth.

The sample we use consists of household heads and their spouses (if applicable) who own at least one housing property in urban China. We restrict people's age to between 16 and legal retirement age, which is 60 for men, 55 for women cadres (government officials and senior managers at state-owned enterprises), and 50 for other women. As a robustness check, we also select a sample including people up to age 65, the cutoff commonly used in studies on developed countries.

\footnotetext{
${ }^{2}$ For more details about the CHFS data and its sampling scheme, see http://www.chfsdata.org.
} 
We infer whether a person is in the labor force based on the following two survey questions. The first one asks “do you currently have a job?” If the answer is "no," then the follow-up question is “why don't you have a job?” The survey lists nine options: (1) student in school; (2) housewife; (3) disabled; (4) have a seasonal job but am not currently in the work season; (5) child-rearing, health or personal reasons; (6) unemployed or haven’t found a job; (7) unwilling to work; (8) retired; (9) others. Following general practice, we define labor force participation rate as the percentage of the working age population who are employed or unemployed but actively searching for jobs (Juhn and Potter, 2006). We classify a person as in the labor force if the person currently has a job; has a seasonal job but is not currently in the work season; or is unemployed.

To estimate the effect of housing wealth change on homeowners' labor force participation, conceptually, we start with the following cross-sectional model:

$$
L F P_{i}=\alpha+\beta \text { HousingWealth } i+\lambda^{\prime} X_{i}+\varepsilon_{i},
$$

where the dependent variable $L F P_{i}$ is a dummy variable set to one if person $i$ is in the labor force. HousingWealth ${ }_{i}$ denotes person $i$ 's housing wealth; $\alpha$ is a constant, and $\varepsilon_{i}$ is the error term. $X_{i}$ represents other control variables including individual and household-level attributes that may affect an individual's labor force participation decision. Individual-level control variables include a female dummy, age and age squared, a dummy indicating good health condition, a dummy for having a college degree or above. Household-level control variables include household size, number of children under age six, household income excluding the labor income of the person in question (a proxy for spouse income), number of housing units owned, total non-housing asset, total household debt, and average number of years owning all housing units.

The problem of estimating model (1) is that unobserved individual heterogeneity may correlate with both housing wealth and labor force participation, biasing the estimated key coefficient $\beta$. Ideally, we would use a panel dataset to estimate an individual fixed effect model. Unfortunately, panel data are not currently available. However, we do have information on housing wealth changes within each family. We 
thus estimate coefficient $\beta$ using the following specification: ${ }^{3}$

$L F P_{i}=\alpha+\beta$ HousingWealthChange $_{i}+\tilde{\beta}$ HousingPurchasePrice $_{i}+\lambda^{\prime} X_{i}+\varepsilon_{i}$

The new independent variables are defined as follows:

HousingWealthChange: The key independent variable of interest. It measures the total change in housing wealth owned by a household, computed as the difference between self-reported current value of housing units and the purchase price of housing units deflated by consumer price indexes. ${ }^{4}$ If a household owns only one housing unit, the total housing wealth change is simply the capital gains (in real term) of this house over the tenure period. If a household owns two or three housing units, the total housing wealth change is the sum of the real capital gains of all units. ${ }^{5}$ In our sample, $99.47 \%$ of homeowners have three or fewer housing units. The survey records price information only up to the third housing unit, so housing wealth is underestimated for the households that own more than three housing units. Note that a household may incur a housing capital loss, so the value of this HousingWealthChange variable may be negative.

HousingPurchasePrice: The total purchase price of a household's housing units, also deflated by consumer price indexes.

\section{[Insert Table 1 here]}

Table 1 presents the summary statistics of these variables. The average labor force participation rate in our sample is $84 \%$, $90 \%$ for men and $77 \%$ for women. The mean housing capital gain is 357,000 yuan and the mean housing purchase price is

\footnotetext{
3 Consider the first difference of equation (1), $\Delta L F P=\beta \Delta$ HousingWealth $+\lambda^{\prime} \Delta X+\Delta \varepsilon$, suppressing index $i$. Since $L F P_{1}=L F P_{0}+\triangle L F P$, expanding $L F P_{0}$ and $\triangle L F P$ we obtain $L F P_{1}=$ $\alpha+\beta \Delta$ HousingWealth $+\beta$ HousingWealth $h_{0}+\lambda^{\prime} X_{1}+\varepsilon_{1}$. Replacing initial housing wealth with housing purchase price, we can estimate $\beta$ with this specification using only data for the current period. Our specification of equation (2) allows the coefficients of housing wealth change and initial housing wealth to be different because we instrument for $\Delta$ HousingWealth only. One caveat is that we assume unobserved individual heterogeneity in the current period is not correlated with initial housing purchase price. We thank the editors for suggesting this interpretation of our empirical specification.

${ }^{4}$ City level consumer price indexes are not available in China. We use the national consumer price index to deflate housing prices to year 2011.

${ }^{5}$ We exclude housing units purchased before 1990. There was almost no housing market in China before 1990. Houses and apartments bought before 1990 are either of very low market value due to depreciation or of limited property rights due to the reform of housing welfare system. In the data, 96.42\% of housing units are bought or built after 1990 .
} 
325,000 yuan. Given the average years of owning a house is 9.42, the imputed annualized appreciation rate in real terms is $8.19 \%$ per year, suggesting that urban homeowners received substantial real capital gains. Housing capital gains are particularly large in the largest cities. For example, homeowners in Beijing, Shanghai, and Guangzhou on average receive 0.99 million yuan in housing capital gains over the tenure period. Our dataset enables us to compute housing wealth change for each homeowner; such cross-household variation in housing wealth change is not available in earlier studies that use housing price at the local level to proxy for housing wealth at the household level.

\section{Identification}

Three possible identification issues may bias the estimate of the key coefficient $\beta$ in equation (2). First, the self-reported housing purchase price and current value may not be precise, so the key variable HousingWealthChange may contain measurement errors, biasing the estimated value of $\beta$ toward zero and making us less likely to find an effect of housing wealth change on labor force participation. Second, there may be omitted variables that correlate with housing wealth change and labor force participation, which could bias our estimates in either direction. For example, unobserved positive shocks to labor demand in local labor markets may increase labor force participation and also drive housing price up, creating an upward bias in estimation. Another example is unobserved individual ability or preference. If people with higher unobserved ability are more likely to be employed and also to buy housing in fast-growing or amenity-rich locations, this would bias the estimates upward. Finally, there is likely a reverse causality issue: employed people tend to buy high-quality housing that appreciates more in value. ${ }^{6}$

We include a set of demographic variables to control for individual and household characteristics and city fixed effects to control for unobserved location attributes. Furthermore, we employ an instrumental variable approach to address the aforementioned identification issues. A valid instrumental variable should be highly correlated with housing wealth change of individual households but uncorrelated with

\footnotetext{
${ }^{6}$ There have been some attempts to address the identification problem in the literature. Lovenheim (2011) uses lagged housing price to instrument for current housing price, but this strategy will not work if high ability people sort into cities with higher housing price appreciation. Zhao and Burge (2015) compare labor supply decisions between homeowners and renters in housing boom and bust periods and find that homeowners increase labor supply during housing bust periods because of housing wealth losses.
} 
households' labor force participation decisions through other channels. Our instrumental variable for HousingWealthChange is the average housing capital gains of other households living in the same community where the household in question lives. $^{7}$ A community is a self-governed commune in cities with a size of between 1000 and 2000 households. $^{8}$ This instrumental variable is intuitively appealing if each household owns only one housing unit. In this case, the price change of one's housing unit should be highly correlated with the price change of his or her neighbor's housing simply because these two housing units are located close to each other; however, this person's decision to work should not be directly affected by the price change of his or her neighbor's house.

When households have two or more housing units that are located in different cities, the relevance of our instrumental variable becomes weakened; the correlation of housing prices between cities is not as strong as within a city or within a community since housing markets are very localized. The CHFS data only records the location of the first housing unit owned by a household; for other housing units, we know only whether they are located within or outside of the city where the household currently lives. Therefore, when using the instrumental variable approach, we restrict our sample to the homeowners whose housing units are all located in the same city where they are currently residing. This reduces the sample size from 5,059 to 4,332.

Table 1 shows that the mean of the instrumental variable is very similar to that of the endogenous variable Housing WealthChange.

A potential threat to our identification strategy is the possibility that people live in the same community behave similarly (in terms of labor force participation) due to common neighborhood characteristics or social interactions. To address these concerns, we conduct two sets of robustness checks. First, we control for many community characteristics, described later. Second, assuming social interaction occurs only among close neighbors, we use average housing capital gains of families who live in other communities but within the same city as an alternative instrumental variable. Reassuringly, the results from these alternative specifications are very similar.

\footnotetext{
${ }^{7}$ The idea of using the price of competing products to instrument for the price of a particular product is well known in the industrial organization literature (e.g., Berry, Levinsohn and Pakes, 1995). Our strategy here is similar to the one adopted by Bayer, Ferreira and McMillan (2007) who use surrounding neighborhood characteristics to instrument for housing price.

${ }^{8}$ This is similar to a census tract (with an average of 1,600 housing units and 4,000 people) defined by the U.S. Census Bureau.
} 


\section{Results}

\section{OLS and Probit results}

We first select the sample of all urban homeowners regardless of where their housing units are located. We estimate equation (2) using both ordinary least squares (OLS) and Probit regressions. All standard errors are clustered at the city level. The results are presented in Table 2. Columns (1)-(3) are the OLS regression results and the coefficients of HousingWealthChange are significant in the full sample but not in the female and male subsamples. Probit estimation results are in Columns (4)-(6). In a few cities all individuals in the sample are in the labor force, therefore these city dummies perfectly predict the dependent variable (18 of them) and are dropped in the maximum likelihood estimation due to "quasi-complete separation.” Column (4) shows that for the full sample, a 100 thousand yuan increase in housing wealth reduces a homeowner's probability to work by 0.16 percentage points (statistically significant at the $1 \%$ level). This effect is not significant when estimated for women and men separately, consistent with the OLS regression results. Since these results may suffer from bias due to measurement errors, omitted variables, and reverse causality, they are suggestive at best.

\section{[Insert Table 2 here]}

The other control variables have reasonable signs and magnitudes. For example, Column (4) shows that women are less likely to work than men, consistent with the fact that, culturally, women's roles are more family-centered. Homeowners with a college degree or above and people with good health condition are more likely to work. Homeowners with more children under six are less likely to work. Most of the coefficients of household-level control variables are not statistically significant. Since these controls are not the focus of our study, to conserve space we will not report them in the ensuing analysis.

\section{SLS and IV Probit results}

We move on to the instrumental variable estimation. Our IV for the change in a household's total housing wealth is the average total housing wealth change of all 
other households in the same community. As mentioned above, we restrict the sample to households whose housing units are all located in the same city, reducing the effective sample size to 4,332.

In the top panel of Table 3, columns (1)-(3) report OLS estimation results using this restricted sample. The coefficients of the key variable HousingWealthChange are all statistically insignificant. When using the two stage least squares (2SLS) regressions, this coefficient is statistically insignificant for the full sample and the male subsample but is significant for the female subsample. The coefficient of HousingWealthChange for the female subsample is -0.0137 , suggesting that a 100 thousand yuan increase in a household's total housing wealth decreases women's probability of joining the labor force by 1.37 percentage points. In other words, a one standard deviation increase in housing wealth change (659,000 yuan) decreases women's probability of working by 9.03 percentage points. This impact is even greater in the largest cities; the mean housing wealth gains in Beijing, Shanghai, and Guangzhou are 0.99 million yuan, implying a 13.56 percentage point decrease in women's probability of working compared with women without housing capital gains. ${ }^{9}$ This finding is consistent with the literature. For example, Henley (2004) points out that compared with men, women have a lower degree of labor market attachment and tend to put more value on home production or child rearing. In response to a housing wealth increase, women tend to decrease labor supply. Column (6) in Table 3 shows that housing capital gains actually increase men's labor force participation although this effect is not statistically significant.

\section{[Insert Table 3 here]}

Table 3 also reports the first-stage results from the 2SLS regressions. The coefficient of the IV is around 0.75 and highly significant across all specifications. The value of the F statistic for weak instruments test in the first stage is much larger than 10 in Columns (4)-(6), suggesting a strong correlation between the IV and the instrumented variable HousingWealthChange. Panel 2 of Table 3 reports the Probit and IV Probit results. They are very similar to the results from the linear probability

\footnotetext{
${ }^{9}$ Since the coefficients on the same variable in Probit models are not comparable across subsamples (Berry et al., 2010; Mood, 2010), we focus on interpreting the key coefficients based on 2SLS regressions.
} 
models. For example, column (5) in Panel 2 shows that when housing capital gains increase by 100 thousand yuan, women's probability of joining labor force will decrease by 1.43 percentage points.

\section{Results on other outcome variables}

We next examine other dimensions of labor supply decisions, including employment, transition to housewife, early retirement, and self-employment outcomes. We report the regression results in Table 4.

In Panel 1, Columns (1)-(3) show that a 100 thousand yuan increase in housing capital gains decreases women's probability of being employed by 0.86 percentage points but increases males' employment rate by 0.94 percentage points. While these coefficients seem reasonable, neither one is precisely estimated. The IV Probit model in Panel 2 shows a similar and marginally significant, negative effect for women but a much smaller (and still insignificant) positive effect for men.

Since an increase in housing wealth reduces women's incentive to work, it is natural to ask what activities they will engage instead. We estimate both 2SLS and IV Probit models using "whether a woman is a housewife or not" as the dependent variable. The results are reported in Column (4) of Table 4. The 2SLS results show that a 100 thousand yuan increase in housing wealth increases the probability of being a housewife by 1.49 percentage points and this effect is significant at the $5 \%$ level. The IV Probit estimate suggests a much larger effect. Both cases show that women tend to substitute housework for market work in response to housing capital gains.

Following the literature (Farnham and Sevak, 2007), we also check if housing capital gains give people incentive to retire earlier. Based on the legal retirement age and the actual retirement status, we create a dummy variable indicating whether a person retired ahead of the legal retirement time and use it as the dependent variable. Columns (5)-(7) show that housing capital gains do not lead homeowners to retire early.

[Insert Table 4 here]

Some studies find that housing capital gains may serve as collateral helping homeowners creating businesses (Disney and Gathergood, 2009; Harding and Rosenthal, 2013; Hurst and Lusardi, 2004). Using data from the 2005 China 
Inter-Census Population Survey and the Chinese Family Panel Studies, $\mathrm{Li}$ and $\mathrm{Wu}$ (2014) find that in urban China high housing prices actually discourage entrepreneurial activities, suggesting that the booming real estate industry crowds out other types of business investment. We also test whether housing capital gains strengthen or weaken homeowners' incentives to own family businesses. The dependent variable equals one if a family is currently running a business. We only use the household head sample for this analysis, assuming the household head is the main economic decision maker in the family. The results are in Column (8) of Table 4. The 2SLS and IV Probit estimates are both negative, but only the IV Probit coefficient is significant (only marginally). Thus there is weak evidence that housing capital gain creates a disincentive for homeowners to own businesses. The IV Probit estimate suggests that a 100 thousand yuan increase in housing capital gains reduces households’ probability to run businesses by 1.49 percentage points.

\section{Robustness checks}

We first address the issue whether the estimated housing wealth effect is confounded by a financial wealth effect. Existing literature finds that compared with housing wealth, financial wealth has a smaller effect on consumption (Case et al., 2005). There has been little evidence whether financial wealth affects labor force participation. Our data contains information about the current value of financial wealth as well as last year's income from financial assets. The questionnaire also indicates whether people have experienced gains or losses since they first started to trade on the stock market. In the first column of Table 5, we examine whether our main result is driven by an effect of financial wealth on women's labor force participation. We use financial asset value and last year's financial income as additional control variables, and also include two dummy variables, Earn Profit and Suffer Loss, to control for the homeowner's performance on the stock market. ${ }^{10}$ Both the 2SLS and IV Probit results show that financial wealth has no effect on women's labor force participation. The effect of housing wealth gains is unchanged after controlling for financial wealth.

[Insert Table 5 here]

10 The break-even status is the base group. 
Our instrument is the average housing capital gain of other households in the same community. As mentioned in Section 3, one might worry that people in the same community behave similarly due to common neighborhood characteristics or social interaction. In Column (2) of Table 5, we estimate the housing wealth effect on women's labor force participation controlling for a variety of community characteristics including whether the community has professional property management, average car value, parking rates, tidiness of streets, cleanness of buildings, traffic congestion level, ratio of green coverage, and the level of economic development within the community. ${ }^{11}$ Both the 2SLS and the IV Probit estimates of the housing wealth effect on women's labor force participation stay essentially the same. Adding community-level controls only slightly reduced the significance level of the estimates.

To address the concern of social interaction among close neighbors, in Column (3) of Table 5, we use average housing capital gain of families who live in other communities within the same city as an alternative instrument since housing values in other communities should also be correlated with the value of the household in question. We are assuming that interaction only occurs among neighbors within the same community but not among families in different communities. Again, both the 2SLS and IV Probit results show that housing capital gains have a negative and significant effect on women's labor force participation when this alternative instrument variable is used. ${ }^{12}$

Many existing studies select a sample of workers aged between 16 and 65 . Although legal retirement age in China is lower, we also estimate the models using a larger sample including individuals aged between 16 and 65. Columns (1)-(3) of Table 6 show that the general pattern is very similar to that in Table 3. For example, the IV Probit results show that a 100 thousand yuan increase in housing wealth reduces the probability of participating labor force by 1.39 percentage points for women but has little effect on men.

\section{[Insert Table 6 here]}

\footnotetext{
11 The sample size is smaller because some community characteristics variables have missing values.

12 The first stage regression shows that the coefficient on the instrumental variable is negative and significant, which indicates that higher housing wealth gains in one community implies lower gains in other communities. That is, housing units in different communities are substitutes.
} 
If a household owns only one housing unit, perceived housing capital gains probably are not as influential as they are to multi-home owners since the single housing unit serves as the primary residential place. We test this hypothesis in Columns (4)-(6) of Table 6 and find that the overall pattern for this subsample is very similar to the full sample and the effect on women's labor force participation is negative, statistically significant, and with slightly smaller magnitudes as expected.

The effect of housing wealth gains on labor force participation may vary over the life cycle. To check this, we estimate 2SLS and IV Probit models for the female subsample based on two demographic characteristics: age and whether there are children under age six in the household. Table 7 presents the results. The 2SLS results show that the negative effect of housing wealth gains on labor force participation is stronger for younger women (aged between 16 and 41, Column (1)), women with children under age six (Column (3)), and particularly so for younger women with children under age six (Column (5)), although most of the coefficients are insignificant. The IV Probit results in Panel 2 shows a stronger pattern: the magnitudes of all coefficients become slightly larger and statistically significant, except for women between the ages of 41 and 60 .

\section{[Insert Table 7 here]}

Overall, our robustness checks confirm our baseline finding that housing wealth gains have a significant, negative effect on women's labor force participation in urban China. $^{13}$

\section{Conclusion}

During the past two decades, Chinese housing markets have experienced rapid price appreciation. We use the 2011 China Household Finance Survey data to estimate how a change in housing value affects homeowners' labor force participation. To deal with potential identification issues, we employ an instrumental variable approach using the average housing capital gains of other households residing in the same

\footnotetext{
${ }^{13}$ Following the suggestion of a referee, we also tried an alternative measure of housing wealth change using the difference between log current value and log purchase price. The results are qualitatively identical to those in Table 3. These results are available upon request.
} 
community as an instrument for housing capital gains in a given household. We find that housing wealth appreciation has a significant, negative impact on women's labor force participation but little impact on men's. A 100 thousand yuan increase in housing wealth reduces women's probability of participating labor force by 1.37 percentage points and increases women's probability of becoming housewives by 1.49 percentage points. These results are consistent with the previous findings that women are more attached to family and substitute market work by home production when experiencing a wealth increase. We also find that housing capital gains reduce homeowners' incentive to run family businesses, and have little effect on the timing of homeowners' retirement. These findings together provide some early empirical evidence on the effect of housing price dynamics on labor market outcomes in urban China.

\section{References:}

Adelino, Manuel, Antoinette Schoar, Felipe Severino, 2015, House prices, collateral, and self-employment, forthcoming in Journal of Financial Economics.

Berry, William D., Jacqueline H. R. DeMeritt, Justin Esarey, 2010, Testing for interaction in binary logit and probit models: is a product term essential? American Journal of Political Science 54, 248-266.

Berry, Steven, James Levinsohn, and Ariel Pakes, 1995, Automobile prices in market equilibrium, Econometrica 63, 841-890.

Bayer, Patrick, Fernando Ferreira, and Robert McMillan, 2007, A unified framework for measuring preferences for schools and neighborhoods, Journal of Political Economy 115, 588-638.

Brown, Jeffrey, Courtney Coile, Scott Weisbenner, 2010, The effect of inheritance receipt on retirement, Review of Economics and Statistics 92, 425-434.

Campbell, John, Joao Cocco, 2007, How do house prices affect consumption? evidence from micro data, Journal of Monetary Economics 54, 591-621.

Case, Karl, John Quigley, Robert Shiller, 2005, Comparing wealth effects: the stock market versus the housing market, Advances in Microeconomics 5, 1-32.

Case, Karl, John Quigley, Robert Shiller, 2013, Wealth effects revisited: 1975-2012, National Bureau of Economic Research Working Paper \#18667.

Carroll, Christopher, Xia Zhou, 2010, Measuring wealth effects using US state data, Working Paper. 
Cooper, Daniel, María José Luengo-Prado, 2015, House price growth when children are teenagers: a path to higher earnings? Journal of Urban Economics 86, 54-72.

Dettling, Lisa, Melissa Kearney, 2014, House prices and birth rates: the impact of the real estate market on the decision to have a baby, Journal of Public Economics 110, 82-100.

Disney, Richard, John Gathergood, 2009, Housing wealth, liquidity constraints and self-employment, Labour Economics 16, 79-88.

Disney, Richard, John Gathergood, 2014, House prices, wealth effects and labour supply, Institute for Fiscal Studies Working Paper W14/25.

Fang, Hanming, Quanlin Gu, Wei Xiong, Li-An Zhou, 2015, Demystifying the Chinese housing boom, NBER Working Paper \#21112.

Farnham, Martin, Purvi Sevak, 2007, Housing wealth and retirement timing, University of Michigan Retirement Research Centre Working Paper 2007-172.

Feng, Shuaizhang, Yingyao Hu, and Robert Moffitt, 2015, Unemployment and labor force participation in China: long run trends and short run dynamics, NBER Working Paper No.21460

Fischer, Will, 2000, Labor supply effects of federal rental subsidies, Journal of Housing Economics 9, 150-174.

Gan, Li, Zhichao Yin, Nan Jia, Shu Xu, Shuang Ma, Lu Zheng 2013, Data you need to know about China: Research report of China Household Finance Survey 2012, Springer.

He, Zhechun, 2015, Estimating the impact of housing prices on household labor supply in the UK, The University of York, Working Paper No.15/19.

Holtz-Eakin, Douglas, David Joulfaian, Harvey Rosen, 1993, The Carnegie conjecture: some empirical evidence, Quarterly Journal of Economics 108, 413-435.

Henley, Andrew, 2004, House price shocks, windfall gains and hours of work: British evidence, Oxford Bulletin of Economics and Statistics 66, 439-456.

Harding, John, Stuart Rosenthal, 2013, Homeowner-entrepreneurs, housing capital gains, and self-employment, Working Paper.

Hurst, Erik, Annamaria Lusardi, 2004, Liquidity constraints, household wealth, and entrepreneurship, Journal of political Economy 112, 319-347.

Imbens, Guido, Donald Rubin, Bruce Sacerdote, 2001, Estimating the effect of unearned income on labor earnings, savings, and consumption: evidence from a survey of lottery players, American Economic Review 91, 778-794. 
Jacob, Brian, Jens Ludwig, 2012, The effects of housing assistance on labor supply: Evidence from a voucher lottery, American Economic Review 102, 272-304.

Joulfaian, David, Mark Wilhelm, 1994, Inheritance and labor supply, Journal of Human Resources 29, 1205-1234.

Johnson, William, 2014, House prices and female labor force participation, Journal of Urban Economics 82, 1-11.

Juhn, Chinhui, and Simon Potter, 2006, Changes in labor force participation in the United States, Journal of Economic Perspectives, 27-46.

Liu, Qian, 2012, Unemployment and labor force participation in urban China, China Economic Review 23, 18-33.

Li, Lixing, Xiaoyu Wu, 2014, Housing prices and entrepreneurship in China, Journal of Comparative Economics 42, 436-449.

Lovenheim, Michael, 2011, The effect of liquid housing wealth on college enrollment, Journal of Labor Economics 29, 741-771.

Lovenheim, Michael F., Kevin J. Mumford, 2013, Do family wealth shocks affect fertility choices? Evidence from the housing market. Review of Economics and Statistics 95, 464-475.

Milosch, Jennifer, 2014, House price shocks and labor supply choices, University of California Unpublished Working Paper.

Mood, Carina, 2010, Logistic regression: why we cannot do what we think we can do, and what we can do about it, European Sociological Review 26, 67-82.

Moretti, Enrico, 2013, Real wage inequality, American Economic Journal: Applied Economics 5, 65-103.

Sheiner, Louise, 1995, Housing prices and the savings of renters, Journal of Urban Economics 38, 94-125.

Starkey, James L., Barbara Port, 1993, Housing cost and married women's labor force participation in 1980, The Social Science Journal 30, 23-45.

Wang, Shing-Yi, 2012, Credit constraints, job mobility, and entrepreneurship: Evidence from a property reform in China, Review of Economics and Statistics 94, 532-551.

Yoshikawa, Hiroshi, Fumio Ohtaka, 1989, An analysis of female labor supply, housing demand and the saving rate in Japan, European Economic Review 33, 997-1023.

Zhao, Lingxiao, and Gregory Burge, 2015, Housing wealth, property taxes and labor supply among the elderly, forthcoming in Journal of Labor Economics. 
Figure 1: Labor force participation rates and housing price in urban China

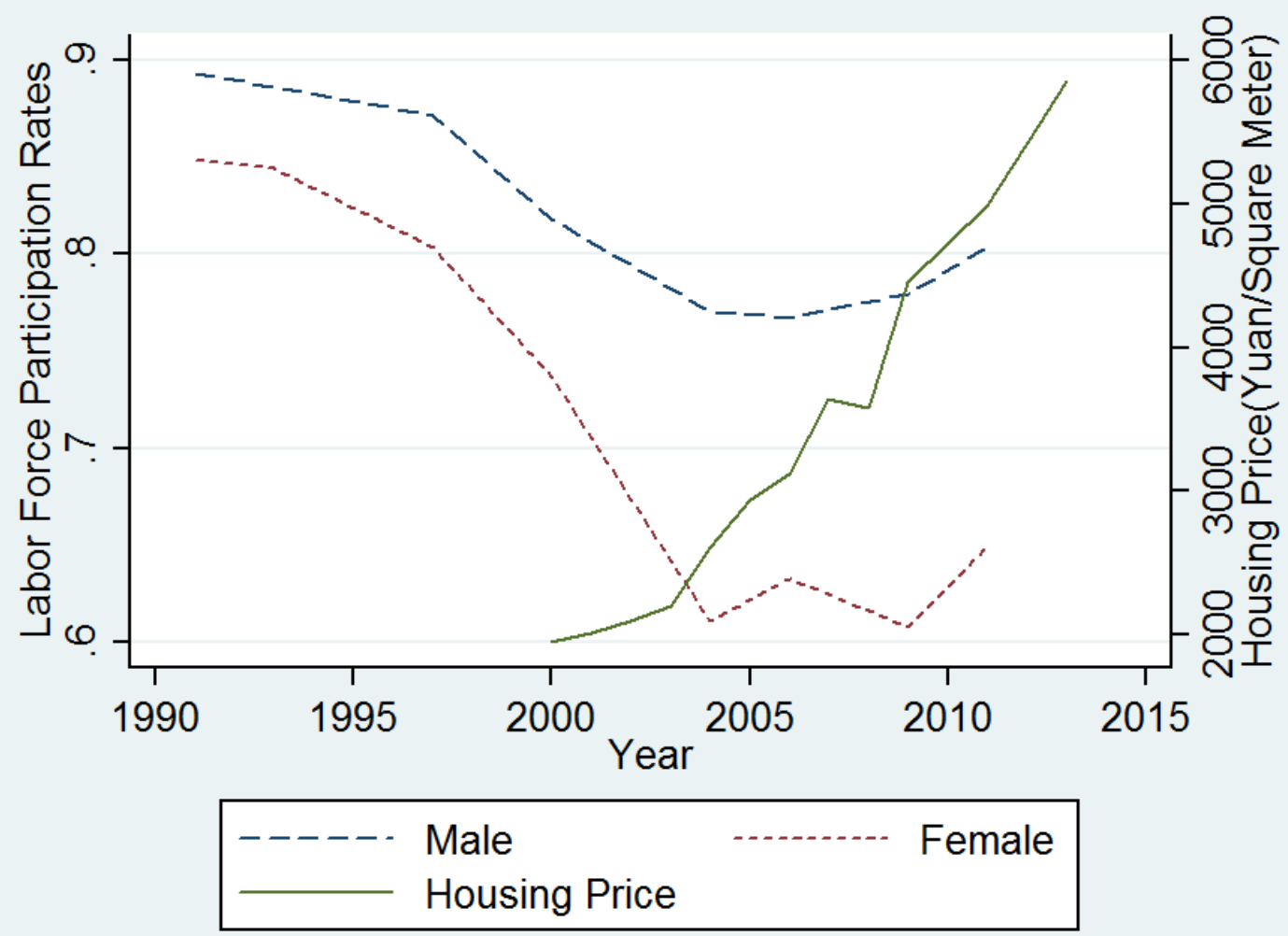

Data Source: China Health and Nutrition Survey (CHNS) and National Bureau of Statistics

Labor force participation rate is defined as the percentage of employed and unemployed people among working age population. It is calculated using data from the China Health and Nutrition Survey (CHNS), a national representative household survey jointly conducted by the University of North Carolina at Chapel Hill and the Chinese Center for Disease Control and Prevention. The web site of CHNS data is http://www.cpc.unc.edu/projects/china. Average residential housing price data are provided by the National Bureau of Statistics (http://data.stats.gov.cn/easyquery.htm?cn=C01). It is calculated by dividing the total sales of residential housing by total floor area of residential housing sold each year. 
Table 1: Summary statistics

\begin{tabular}{|c|c|c|c|c|c|}
\hline Variable description & Obs. & Mean & $\begin{array}{l}\text { Std. } \\
\text { Dev. }\end{array}$ & Min. & Max. \\
\hline $\begin{array}{l}\text { LFP dummy (=1 if a person is in the labor } \\
\text { force) }\end{array}$ & 5,059 & 0.84 & 0.36 & 0 & 1 \\
\hline LFP dummy for female sample & 2,229 & 0.77 & 0.42 & 0 & 1 \\
\hline LFP dummy for male sample & 2,830 & 0.90 & 0.30 & 0 & 1 \\
\hline HousingWealthChange & 5,059 & 3.57 & 6.54 & -37.90 & 63.01 \\
\hline HousingWealthChange for the IV sample & 4,332 & 3.68 & 6.58 & -12.55 & 63.01 \\
\hline $\begin{array}{l}\text { Instrument variable for HousingWealthChange } \\
\text { (average housing capital gains of other } \\
\text { households living in the same community) }\end{array}$ & 4,332 & 3.71 & 5.20 & -0.39 & 24.98 \\
\hline $\begin{array}{l}\text { Instrument variable for HousingWealthChange } \\
\text { (average housing capital gains of households } \\
\text { in other communities in the same city) }\end{array}$ & 1,768 & 3.78 & 5.04 & -0.28 & 19.88 \\
\hline Total purchase price of housing units & 5,059 & 3.25 & 5.13 & 0.00 & 77.90 \\
\hline Average purchase years & 5,059 & 9.42 & 4.96 & 1.00 & 21.00 \\
\hline Number of housing units owned & 5,059 & 1.26 & 0.54 & 1.00 & 11.00 \\
\hline Female dummy & 5,059 & 0.44 & 0.50 & 0.00 & 1.00 \\
\hline Age & 5,059 & 41.25 & 8.87 & 16.00 & 60.00 \\
\hline $\begin{array}{l}\text { College dummy (=1 with a college degree or } \\
\text { above) }\end{array}$ & 5,059 & 0.14 & 0.35 & 0 & 1 \\
\hline $\begin{array}{l}\text { Good health dummy (=1 if health condition is } \\
\text { good or better) }\end{array}$ & 5,059 & 0.42 & 0.49 & 0 & 1 \\
\hline Number of Children under age 6 & 5,059 & 0.25 & 0.48 & 0.00 & 4.00 \\
\hline $\begin{array}{l}\text { Household income (excluding individual labor } \\
\text { income) }\end{array}$ & 5,059 & 0.56 & 1.71 & -4.91 & 30.00 \\
\hline Household size & 5,059 & 3.47 & 1.14 & 1.00 & 9.00 \\
\hline Household assets (excluding housing) & 5,059 & 2.61 & 7.96 & 0.00 & 116.4 \\
\hline Household debts & 5,059 & 0.79 & 3.46 & 0.00 & 107.8 \\
\hline Employed dummy & 5,059 & 0.77 & 0.42 & 0.00 & 1.00 \\
\hline Own family business dummy & 2,423 & 0.18 & 0.38 & 0.00 & 1.00 \\
\hline Retired early dummy & 5,059 & 0.04 & 0.20 & 0.00 & 1.00 \\
\hline Housewife dummy & 5,059 & 0.07 & 0.26 & 0.00 & 1.00 \\
\hline
\end{tabular}

Note: The sample of size 5,059 includes homeowners who own at least one housing unit and meet other criteria described in Section 3 of the paper. The sample of size 4,332 keeps the homeowners whose housing units are located in the same city. All monetary values are in 100,000 yuan using 2011 value adjusted by annual consumer price index, when applicable. 
Table 2: Effect of housing wealth change on labor force participation, OLS and Probit estimation

\begin{tabular}{|c|c|c|c|c|c|c|}
\hline Variables & $\begin{array}{c}\text { (1) } \\
\text { Full } \\
\text { Sample }\end{array}$ & $\begin{array}{c}\text { (2) } \\
\text { OLS } \\
\text { Female } \\
\text { Sample }\end{array}$ & $\begin{array}{c}\text { Male } \\
\text { Sample }\end{array}$ & $\begin{array}{c}\text { Full } \\
\text { Sample }\end{array}$ & $\begin{array}{c}(5) \\
\text { Probit } \\
\text { Female } \\
\text { Sample } \\
\end{array}$ & $\begin{array}{l}\text { Male } \\
\text { Sample }\end{array}$ \\
\hline HousingWealthChange & $\begin{array}{l}-0.0014^{* *} \\
(0.0005)\end{array}$ & $\begin{array}{l}-0.0017 \\
(0.0015)\end{array}$ & $\begin{array}{l}-0.0008 \\
(0.0011)\end{array}$ & $\begin{array}{c}-0.0016^{* * *} \\
(0.0006)\end{array}$ & $\begin{array}{l}-0.0022 \\
(0.0015)\end{array}$ & $\begin{array}{c}-0.0011 \\
(0.0007)\end{array}$ \\
\hline Female dummy & $\begin{array}{c}-0.1624^{* * *} \\
(0.0088)\end{array}$ & & & $\begin{array}{c}-0.1793^{* * *} \\
(0.0094)\end{array}$ & & \\
\hline Age & $\begin{array}{l}0.0609^{* * *} \\
(0.0058)\end{array}$ & $\begin{array}{l}0.0787^{* * *} \\
(0.0130)\end{array}$ & $\begin{array}{c}0.0577^{* * *} \\
(0.0056)\end{array}$ & $\begin{array}{l}0.0574^{* * *} \\
(0.0038)\end{array}$ & $\begin{array}{l}0.0766^{* * *} \\
(0.0116)\end{array}$ & $\begin{array}{l}0.0404^{* * *} \\
(0.0025)\end{array}$ \\
\hline Age squared & $\begin{array}{c}-0.0008^{* * *} \\
(0.0001)\end{array}$ & $\begin{array}{c}-0.0010^{* * *} \\
(0.0002)\end{array}$ & $\begin{array}{c}-0.0008^{* * *} \\
(0.0001)\end{array}$ & $\begin{array}{c}-0.0008^{* * *} \\
(0.0000)\end{array}$ & $\begin{array}{c}-0.0010^{* * *} \\
(0.0002)\end{array}$ & $\begin{array}{c}-0.0005^{* * *} \\
(0.0000)\end{array}$ \\
\hline College dummy & $\begin{array}{c}0.0677^{* * *} \\
(0.0111)\end{array}$ & $\begin{array}{l}0.1270^{* * *} \\
(0.0221)\end{array}$ & $\begin{array}{l}0.0249^{* *} \\
(0.0104)\end{array}$ & $\begin{array}{l}0.0895^{* * *} \\
(0.0182)\end{array}$ & $\begin{array}{l}0.1692^{* * *} \\
(0.0290)\end{array}$ & $\begin{array}{l}0.0352^{* *} \\
(0.0151)\end{array}$ \\
\hline Good health dummy & $\begin{array}{c}0.1869^{* * *} \\
(0.0100)\end{array}$ & $\begin{array}{l}0.3253^{* * *} \\
(0.0144)\end{array}$ & $\begin{array}{l}0.0765^{* * *} \\
(0.0118)\end{array}$ & $\begin{array}{l}0.2269^{* * *} \\
(0.0135)\end{array}$ & $\begin{array}{l}0.4259^{* * *} \\
(0.0258)\end{array}$ & $\begin{array}{l}0.1002^{* * *} \\
(0.0121)\end{array}$ \\
\hline $\begin{array}{l}\text { Number of Children } \\
\text { under } 6\end{array}$ & $\begin{array}{c}-0.0467^{* * *} \\
(0.0126)\end{array}$ & $\begin{array}{c}-0.1149^{* * *} \\
(0.0215)\end{array}$ & $\begin{array}{c}0.0110 \\
(0.0121)\end{array}$ & $\begin{array}{c}-0.0399^{* * *} \\
(0.0118)\end{array}$ & $\begin{array}{c}-0.1058^{* * *} \\
(0.0192)\end{array}$ & $\begin{array}{c}0.0153 \\
(0.0145)\end{array}$ \\
\hline Household size & $\begin{array}{c}0.0038 \\
(0.0052)\end{array}$ & $\begin{array}{c}0.0004 \\
(0.0075)\end{array}$ & $\begin{array}{c}0.0011 \\
(0.0048)\end{array}$ & $\begin{array}{c}0.0053 \\
(0.0047)\end{array}$ & $\begin{array}{c}0.0038 \\
(0.0070)\end{array}$ & $\begin{array}{l}-0.0001 \\
(0.0045)\end{array}$ \\
\hline Household income & $\begin{array}{l}-0.0014 \\
(0.0025)\end{array}$ & $\begin{array}{c}0.0018 \\
(0.0040)\end{array}$ & $\begin{array}{l}-0.0031 \\
(0.0026)\end{array}$ & $\begin{array}{l}-0.0006 \\
(0.0020)\end{array}$ & $\begin{array}{c}0.0022 \\
(0.0028)\end{array}$ & $\begin{array}{l}-0.0018 \\
(0.0018)\end{array}$ \\
\hline $\begin{array}{l}\text { Total purchase } \\
\text { price of housing units }\end{array}$ & $\begin{array}{l}-0.0017 \\
(0.0023)\end{array}$ & $\begin{array}{c}-0.0041^{* *} \\
(0.0019)\end{array}$ & $\begin{array}{l}-0.0003 \\
(0.0024)\end{array}$ & $\begin{array}{l}-0.0017 \\
(0.0020)\end{array}$ & $\begin{array}{c}-0.0037^{* *} \\
(0.0017)\end{array}$ & $\begin{array}{l}-0.0009 \\
(0.0017)\end{array}$ \\
\hline $\begin{array}{l}\text { Number of housing } \\
\text { units owned }\end{array}$ & $\begin{array}{l}0.0220^{*} \\
(0.0124)\end{array}$ & $\begin{array}{l}0.0458^{* * *} \\
(0.0157)\end{array}$ & $\begin{array}{c}0.0068 \\
(0.0144)\end{array}$ & $\begin{array}{c}0.0181 \\
(0.0123)\end{array}$ & $\begin{array}{l}0.0474^{* * * *} \\
(0.0176)\end{array}$ & $\begin{array}{c}0.0021 \\
(0.0104)\end{array}$ \\
\hline Average purchase years & $\begin{array}{c}0.0006 \\
(0.0013)\end{array}$ & $\begin{array}{l}-0.0017 \\
(0.0019)\end{array}$ & $\begin{array}{l}0.0025^{* *} \\
(0.0012)\end{array}$ & $\begin{array}{c}0.0004 \\
(0.0012)\end{array}$ & $\begin{array}{l}-0.0013 \\
(0.0019)\end{array}$ & $\begin{array}{c}0.0021^{*} \\
(0.0012)\end{array}$ \\
\hline Household assets & $\begin{array}{l}-0.0013^{*} \\
(0.0007)\end{array}$ & $\begin{array}{l}-0.0019^{*} \\
(0.0010)\end{array}$ & $\begin{array}{l}-0.0003 \\
(0.0005)\end{array}$ & $\begin{array}{l}-0.0011 \\
(0.0007)\end{array}$ & $\begin{array}{l}-0.0016 \\
(0.0011)\end{array}$ & $\begin{array}{l}-0.0004 \\
(0.0008)\end{array}$ \\
\hline Household debts & $\begin{array}{c}0.0025 \\
(0.0016)\end{array}$ & $\begin{array}{l}0.0057^{* *} \\
(0.0024)\end{array}$ & $\begin{array}{l}-0.0003 \\
(0.0017)\end{array}$ & $\begin{array}{c}0.0031 \\
(0.0025)\end{array}$ & $\begin{array}{c}0.0072 \\
(0.0051)\end{array}$ & $\begin{array}{c}0.0007 \\
(0.0016)\end{array}$ \\
\hline Sample size & 5,059 & 2,229 & 2,830 & 5,041 & 2,221 & 2,736 \\
\hline $\mathrm{R}^{2}$ (Pseudo $\mathrm{R}^{2}$ ) & 0.1840 & 0.2146 & 0.1829 & 0.2554 & 0.2498 & 0.2660 \\
\hline
\end{tabular}

Note: A constant term and city fixed effects are included in all the models, but their coefficients are not reported here. Standard errors are clustered at the city level and listed in parentheses. Coefficients in Columns (4)-(6) are marginal effects. ${ }^{* * *},{ }^{* *}$, and ${ }^{*}$ indicate significance at the $1 \%, 5 \%$, and $10 \%$ levels, respectively. 
Table 3: Effect of housing wealth change on labor force participation, IV estimation

\begin{tabular}{|c|c|c|c|c|c|c|}
\hline Variables & $\begin{array}{c}(1) \\
\text { Full } \\
\text { sample }\end{array}$ & $\begin{array}{c}\text { (2) } \\
\text { Female } \\
\text { sample }\end{array}$ & $\begin{array}{c}(3) \\
\text { Male } \\
\text { sample }\end{array}$ & $\begin{array}{c}(4) \\
\text { Full } \\
\text { sample }\end{array}$ & $\begin{array}{c}\text { (5) } \\
\text { Female } \\
\text { sample }\end{array}$ & $\begin{array}{c}(6) \\
\text { Male } \\
\text { sample }\end{array}$ \\
\hline \multicolumn{7}{|c|}{ Panel 1: Linear Probability Model Results } \\
\hline & & OLS & & & 2SLS & \\
\hline \multirow[t]{2}{*}{ HousingWealthChange } & -0.0011 & -0.0013 & -0.0002 & -0.0038 & $-0.0137^{* *}$ & 0.0055 \\
\hline & $(0.0010)$ & $(0.0017)$ & $(0.0017)$ & $(0.0050)$ & $(0.0056)$ & $(0.0069)$ \\
\hline Sample size & 4,332 & 1,896 & 2,436 & 4,332 & 1,896 & 2,436 \\
\hline \multirow[t]{2}{*}{$\mathrm{R}^{2}\left(\right.$ Centered $\mathrm{R}^{2}$ ) } & 0.1820 & 0.2139 & 0.1953 & 0.1642 & 0.1734 & 0.1556 \\
\hline & & & & \multicolumn{3}{|c|}{ First-stage regression } \\
\hline Instrumental variable for & & & & $0.7500^{* * *}$ & $0.7517^{* * *}$ & $0.7513^{* * *}$ \\
\hline HousingWealthChange & & & & $(0.1080)$ & $(0.1403)$ & $(0.0924)$ \\
\hline First stage $\mathrm{F}$ test & & & & 48.19 & 28.69 & 66.07 \\
\hline \multicolumn{7}{|c|}{ Panel 2: Probit Results } \\
\hline \multirow{3}{*}{ HousingWealthChange } & & Probit & & & IV Probit & \\
\hline & -0.0011 & -0.0018 & -0.0005 & -0.0034 & $-0.0143^{* *}$ & 0.0025 \\
\hline & $(0.0010)$ & $(0.0019)$ & $(0.0014)$ & $(0.0043)$ & $(0.0057)$ & $(0.0053)$ \\
\hline Sample size & 4,317 & 1,889 & 2,356 & 4,317 & 1,889 & 2,356 \\
\hline Pseudo $\mathrm{R}^{2}$ & 0.2472 & 0.2470 & 0.2694 & & & \\
\hline
\end{tabular}

Note: All models include a constant term and the same set of control variables as in Table 2, but their coefficients are not reported here. Standard errors are clustered at the city level and listed in parentheses. First-stage F tests report the Kleibergen-Paap rk Wald F statistic produced in the first stage of the 2SLS regressions. Coefficients for Probit and IV Probit models are marginal effects. ${ }^{* * *},{ }^{* *}$, and ${ }^{*}$ indicate significance at the $1 \%, 5 \%$, and $10 \%$ levels, respectively. 
Table 4: Effect of housing wealth change on other labor supply decisions

\begin{tabular}{|c|c|c|c|c|c|c|c|c|}
\hline & (1) & $(2)$ & (3) & (4) & (5) & (6) & (7) & $(8)$ \\
\hline & & Employment & & Housewife & & $\begin{array}{c}\text { Early } \\
\text { retirement }\end{array}$ & & $\begin{array}{c}\text { Own } \\
\text { business }\end{array}$ \\
\hline & $\begin{array}{c}\text { Full } \\
\text { sample }\end{array}$ & $\begin{array}{l}\text { Female } \\
\text { sample }\end{array}$ & $\begin{array}{c}\text { Male } \\
\text { sample }\end{array}$ & $\begin{array}{l}\text { Female } \\
\text { sample }\end{array}$ & $\begin{array}{c}\text { Full } \\
\text { sample }\end{array}$ & $\begin{array}{l}\text { Female } \\
\text { sample }\end{array}$ & $\begin{array}{c}\text { Male } \\
\text { Sample } \\
\end{array}$ & $\begin{array}{c}\text { Full } \\
\text { sample }\end{array}$ \\
\hline \multicolumn{9}{|c|}{ Panel 1: 2SLS } \\
\hline HousingWealthChange & $\begin{array}{c}0.0010 \\
(0.0068)\end{array}$ & $\begin{array}{l}-0.0086 \\
(0.0060)\end{array}$ & $\begin{array}{c}0.0094 \\
(0.0109)\end{array}$ & $\begin{array}{c}0.0149^{* * *} \\
(0.0053)\end{array}$ & $\begin{array}{c}-0.0015 \\
(0.0050)\end{array}$ & $\begin{array}{c}0.0039 \\
(0.0046)\end{array}$ & $\begin{array}{c}-0.0054 \\
(0.0058)\end{array}$ & $\begin{array}{c}-0.0058 \\
(0.0061)\end{array}$ \\
\hline Sample size & 4,332 & 1,896 & 2,436 & 1,896 & 4,332 & 1,896 & 2,436 & 2,423 \\
\hline $\mathrm{R}^{2}$ (Centered $\mathrm{R}^{2}$ ) & 0.2246 & 0.2593 & 0.1795 & 0.1308 & 0.1746 & 0.1242 & 0.1932 & 0.1277 \\
\hline \multicolumn{9}{|c|}{ First-stage regression } \\
\hline Instrumental variable for & $0.7500^{* * *}$ & $0.7517^{* * *}$ & $0.7513^{* * *}$ & $0.7517^{* * *}$ & $0.7500^{* * *}$ & $0.7517^{* * *}$ & $0.7513^{* * *}$ & $0.7308^{* * *}$ \\
\hline HousingWealthChange & $(0.1080)$ & $(0.1403)$ & $(0.0924)$ & $(0.1403)$ & $(0.1080)$ & $(0.1403)$ & $(0.0924)$ & $(0.0807)$ \\
\hline First stage $\mathrm{F}$ test & 48.19 & 28.69 & 66.07 & 28.69 & 48.19 & 28.69 & 66.07 & 81.99 \\
\hline \multicolumn{9}{|c|}{ Panel 2: IV Probit } \\
\hline HousingWealthChange & 0.0006 & $-0.0100^{*}$ & 0.0056 & $0.0303^{* * *}$ & 0.0006 & 0.0067 & -0.0017 & $-0.0149^{*}$ \\
\hline & $(0.0062)$ & $(0.0061)$ & $(0.0089)$ & $(0.0114)$ & $(0.0027)$ & $(0.0057)$ & $(0.0030)$ & $(0.0084)$ \\
\hline Sample size & 4,332 & 1,896 & 2,427 & 1,205 & 3,795 & 990 & 2,114 & 2,432 \\
\hline
\end{tabular}

Note: All models include a constant term and the same set of control variables as in Table 2, but their coefficients are not reported here. Standard errors are clustered at the city level and listed in parentheses. First-stage F tests report the Kleibergen-Paap rk Wald F statistic produced in the first stage of the 2SLS regressions. Coefficients for Probit and IV Probit models are marginal effects. ${ }^{* * *},{ }^{* *}$, and ${ }^{*}$ indicate significance at the $1 \%, 5 \%$, and $10 \%$ levels, respectively. 
Table 5: Effect of housing wealth change on female labor force participation, robustness checks

(1) (2) (3)

\begin{tabular}{|c|c|c|c|}
\hline & $\begin{array}{c}\text { Financial } \\
\text { Wealth Effect }\end{array}$ & $\begin{array}{c}\text { Community } \\
\text { Characteristics }\end{array}$ & $\begin{array}{c}\text { (3) } \\
\text { IV: Housing } \\
\text { capital gains } \\
\text { of other } \\
\text { communities } \\
\text { in the same } \\
\text { city }\end{array}$ \\
\hline HousingWealthChange & $\begin{array}{l}\text { Panel 1: 2SL } \\
-0.0139^{* *} \\
(0.0056)\end{array}$ & $\begin{array}{l}-0.0157^{* *} \\
(0.0080)\end{array}$ & $\begin{array}{c}-0.0107^{* *} \\
(0.0049)\end{array}$ \\
\hline Financial Asset & $\begin{array}{l}-0.0027 \\
(0.0038)\end{array}$ & & \\
\hline Financial Income & $\begin{array}{l}-0.0899 \\
(0.1327)\end{array}$ & & \\
\hline Earn Profit & $\begin{array}{c}0.0198 \\
(0.0604)\end{array}$ & & \\
\hline Suffer Loss & $\begin{array}{c}0.0289 \\
(0.0386)\end{array}$ & & \\
\hline Community Characteristics & No & Yes & No \\
\hline Sample size & 1,896 & 1,629 & 1,768 \\
\hline $\mathrm{R}^{2}$ (Centered $\mathrm{R}^{2}$ ) & 0.1734 & 0.1718 & 0.1819 \\
\hline $\begin{array}{l}\text { Instrument variable for } \\
\text { HousingWealthChange } \\
\text { First stage F test }\end{array}$ & $\begin{array}{c}\text { First-stage regre } \\
\begin{array}{c}0.7527^{* * *} \\
(0.1356) \\
30.80\end{array}\end{array}$ & $\begin{array}{l}\text { sion } \\
\qquad \begin{array}{c}0.6595^{* * *} \\
(0.1556) \\
17.95\end{array}\end{array}$ & $\begin{array}{c}-3.0377^{* * *} \\
(0.7078) \\
18.42\end{array}$ \\
\hline \multicolumn{4}{|c|}{ Panel 2: IV Probit } \\
\hline HousingWealthChange & $\begin{array}{l}-0.0147^{* *} \\
(0.0058)\end{array}$ & $\begin{array}{l}-0.0146^{*} \\
(0.0078)\end{array}$ & $\begin{array}{c}-0.0121^{* * *} \\
(0.0046)\end{array}$ \\
\hline Financial Asset & $\begin{array}{l}-0.0032 \\
(0.0040)\end{array}$ & & \\
\hline Financial Income & $\begin{array}{l}-0.0770 \\
(0.1090)\end{array}$ & & \\
\hline Earn Profit & $\begin{array}{c}0.0087 \\
(0.0652)\end{array}$ & & \\
\hline Suffer Loss & $\begin{array}{c}0.0447 \\
(0.0521)\end{array}$ & & \\
\hline Community Characteristics & No & Yes & No \\
\hline Sample size & 1,889 & 1,629 & 1,768 \\
\hline
\end{tabular}

Note: All models are estimated using an only-female sample. All models include a constant term and the same set of control variables as in Table 2 but their coefficients are not reported here. Standard errors are clustered at the city level and listed in the parentheses. First-stage F tests report the Kleibergen-Paap rk Wald F statistic produced in the first stage of the 2SLS regressions. Coefficients for Probit and IV Probit models are marginal effects. ${ }^{* * *},{ }^{* *}$, and ${ }^{*}$ indicate significance at the $1 \%, 5 \%$, and $10 \%$ levels, respectively. 
Table 6: Effect of housing wealth change on labor force participation, alternative samples

\begin{tabular}{|c|c|c|c|c|c|c|}
\hline & (1) & $(2)$ & (3) & (4) & (5) & (6) \\
\hline & \multicolumn{3}{|c|}{$16 \leq$ age $\leq 65$} & \multicolumn{3}{|c|}{ Have only one housing unit } \\
\hline & $\begin{array}{c}\text { Full } \\
\text { sample }\end{array}$ & $\begin{array}{l}\text { Female } \\
\text { sample }\end{array}$ & $\begin{array}{c}\text { Male } \\
\text { sample }\end{array}$ & $\begin{array}{c}\text { Full } \\
\text { sample }\end{array}$ & $\begin{array}{l}\text { Female } \\
\text { sample }\end{array}$ & $\begin{array}{c}\text { Male } \\
\text { sample }\end{array}$ \\
\hline \multicolumn{7}{|c|}{ Panel 1: 2SLS } \\
\hline HousingWealthChange & $\begin{array}{c}-0.0047 \\
(0.0054)\end{array}$ & $\begin{array}{l}-0.0132 \\
(0.0086)\end{array}$ & $\begin{array}{c}0.0038 \\
(0.0074)\end{array}$ & $\begin{array}{c}-0.0036 \\
(0.0064)\end{array}$ & $\begin{array}{l}-0.0108^{* *} \\
(0.0051)\end{array}$ & $\begin{array}{c}0.0045 \\
(0.0072)\end{array}$ \\
\hline Sample size & 5,427 & 2,774 & 2,653 & 3,429 & 1,512 & 1,917 \\
\hline $\mathrm{R}^{2}$ (Centered $\mathrm{R}^{2}$ ) & 0.3202 & 0.2772 & 0.2987 & 0.1360 & 0.1998 & 0.1742 \\
\hline \multicolumn{7}{|c|}{ First-stage regression } \\
\hline Instrumental variable for & $0.7353^{* * *}$ & $0.7293^{* * *}$ & $0.7438^{* * *}$ & $0.8068^{* * *}$ & $0.8134^{* * *}$ & $0.8026^{* * *}$ \\
\hline HousingWealthChange & $(0.1118)$ & $(0.1178)$ & $(0.1072)$ & $(0.1201)$ & $(0.1678)$ & $(0.0938)$ \\
\hline First stage $\mathrm{F}$ test & 43.23 & 38.33 & 48.10 & 45.16 & 23.49 & 73.23 \\
\hline \multicolumn{7}{|c|}{ Panel 2: IV Probit } \\
\hline HousingWealthChange & $\begin{array}{c}-0.0049 \\
(0.0044)\end{array}$ & $\begin{array}{l}-0.0139^{*} \\
(0.0073)\end{array}$ & $\begin{array}{c}0.0025 \\
(0.0056)\end{array}$ & $\begin{array}{l}-0.0045 \\
(0.0061)\end{array}$ & $\begin{array}{c}-0.0125^{* * *} \\
(0.0048)\end{array}$ & $\begin{array}{c}0.0020 \\
(0.0058)\end{array}$ \\
\hline Sample size & 5,427 & 2,774 & 2,609 & 3,414 & 1,505 & 1,812 \\
\hline
\end{tabular}

Note: All models include a constant term and the same set of control variables as in Table 2, but their coefficients are not reported here. Standard errors are clustered at the city level and listed in parentheses. First-stage F tests report the Kleibergen-Paap rk Wald F statistic produced in the first stage of the 2SLS regressions. Coefficients for Probit and IV Probit models are marginal effects. ${ }^{* * *},{ }^{* *}$, and ${ }^{*}$ indicate significance at the $1 \%, 5 \%$, and $10 \%$ levels, respectively. 
Table 7: Effect of housing wealth change on female labor force participation by demographics

(1)

(2) $16 \leq$ age $\leq 41$

Variables Panel 1: 2SLS

HousingWealthChange

$$
-0.0198^{* *}
$$

$-0.0045$

(0.0078)

$(0.0070)$

0.2198

0.1527

1,097

799

(3)

(4)

Without children

(5)

$16 \leq$ age $\leq 41$ and with children

$\mathrm{R}^{2}$ (Centered $\mathrm{R}^{2}$ )

Sample size

799

First-stage regression

Instrumental variable for
HousingWealthChange

$0.6637^{* * *}$

$0.7805^{* * *}$

(0.0723)

(0.2700)

$0.5557^{* *}$

(0.1749)

$-0.0365$

$-0.0106$

$-0.0225$

$0.0237)$

(0.0067)

(0.0282)

2270

8.36

10.10

Panel 2: IV Probit

\begin{tabular}{lccccc} 
HousingWealthChange & $-0.0253^{* *}$ & -0.0068 & $-0.0436^{* *}$ & $-0.0119^{*}$ & $-0.0883^{* * *}$ \\
& $(0.0105)$ & $(0.0066)$ & $(0.0189)$ & $(0.0063)$ & $(0.0300)$ \\
Sample size & 662 & 780 & 415 & 1,439 & 195 \\
\hline
\end{tabular}

Note: All models use the female subsample. All models include a constant term and the same set of control variables as in Table 2, but their coefficients are not reported here. Standard errors are clustered at the city level and listed in parentheses. First-stage F tests report the Kleibergen-Paap rk Wald F statistic produced in the first stage of the 2SLS regressions. Coefficients for Probit and IV Probit models are marginal effects. ${ }^{* * *},{ }^{* *}$, and ${ }^{*}$ indicate significance at the $1 \%, 5 \%$, and $10 \%$ levels, respectively. 